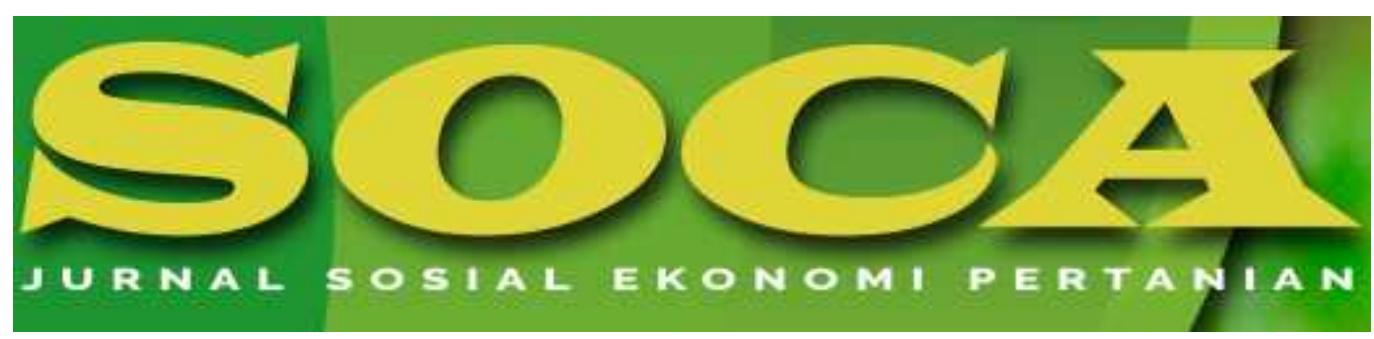

https://ojs.unud.ac.id/index.php/soca

\title{
BAURAN PEMASARAN OLAHAN LIDAH BUAYA TERHADAP KEPUTUSAN PEMBELIAN SECARA E-COMMERCE UKM I SUN VERA
}

\author{
Lili Suryati, Eva Dolorosa dan Shenny Oktoriana \\ Prodi Agribisnis, Fakultas Pertanian,Universitas Tanjungpura Pontianak, Kalimantan Barat \\ e-mail: lilisuryati@student.untan.ac.id \\ HP: 085392237476
}

\begin{tabular}{l} 
Kata Kunci: \\
Bauran \\
pemasaran, I \\
Sun Vera, \\
keputusan \\
pembelian, e- \\
commerce, SEM \\
\hline
\end{tabular}


memudahkan konsumen dalam hal pembayaran seperti Dana, Gopay, Alfamart/Indomaret, Cash On Delivery dan lainnya.

MARKETING MIX ALOE VERA PROCESSED TOWARD PURCHASE DECISION ACCORDING TO E-COMMERCE UKM I SUN VERA

\section{Keywords: $\quad E-$} commerce, I Sun Vera, marketing mix, purchase desicions, SEM

\begin{abstract}
Abstrak
The rapid growth in internet users in Indonesia makes the e-commerce business increasingly fierce by business people. UKM I Sun Vera is one of the UKM that develops $e$ commerce marketing business of processed aloe vera products, but in the implementation of UKM I Sun Vera still experience some obstacles such as sales promotions carried out less than the maximum, less skilled labor, limited knowledge of applications or online business systems so that consumer purchasing decisions in $e^{-}$ commerce are low on the product I SUN VERA. The purpose of this study was to analyze the effect of aloe vera marketing mix on the purchasing decision of e-commerce UKM I Sun Vera. This study used a survey method with quantitative descriptive analysis namely Structural Equation Modeling (SEM) with LISREL 8.80 software. Sampling technique used on this research is purposive sampling, that involved 110 respondents. Data were collected through e-questionnaire with google form. The results showed that the variable marketing mix of products, prices and processes influence purchasing decisions. UKM I Sun Vera must pay attention to the nutritional content of the product on the packaging and add variety to the product uploaded in online marketing media. Sun Vera I SMEs must also pay attention to the affordability of product prices by making product innovations in various sizes and shapes and by adding online payment alternatives to facilitate consumers in terms of payment such as Dana, Gopay, Alfamart / Indomaret, Cash On Delivery and others.
\end{abstract}

How to Cite (APA 6 $6^{\text {th }}$ Style):

Suryati, L., Dolorosa, E., \& Oktoriana, S. (2020). Bauran Pemasaran Olahan Lidah Buaya Terhadap Keputusan Pembelian Secara E-Commerce Ukm I Sun Vera. SOCA: Jurnal Sosial Ekonomi Pertanian, 14(1), 132-145.

https://doi.org/https://doi.org/10.24843/SOCA.2020.v14.i01.p11

\section{PENDAHULUAN}

Saat ini banyak pelaku bisnis e-commerce mengalami perkembangan dengan pesat, adanya perkembangan pesat ini disebabkan oleh adanya ide kreatif dan inovatif. Seiring dengan adanya ide tersebut konsep pemasaran juga turut berkembang. E-commerce memiliki sasaran pasar, hal ini dikarenakan semakin lama semakin banyak pengguna internet yang berkembang pada masyarakat luas baik pemerintah maupun umum (Turban, 2002). UKM I Sun Vera melakukan pemasaran 
produknya secara e-commerce karena melihat adanya peluang bisnis dari peningkatan pengguna internet penduduk Indonesia setiap tahunnya, peningkatan ini dapat dijadikan peluang bisnis bagi UKM tersebut untuk memasarkan produknya dan meningkatkan keuntungan yang diperoleh menjadi lebih besar, keuntungan dari pemasaran produk secara e-commerce sendiri yakni berupa kemudahan dalam pelayanan, biaya pemasaran atau promosi lebih murah, tidak terbatasnya ruang dan waktu serta banyak keuntungan lainnya. UKM I SUN VERA mulai memasarkan produk secara e-commerce sejak tahun 2016. Jenis e-commerce yang digunakan yaitu $\mathrm{C} 2 \mathrm{C}$ (Customer to Customer), yang saat ini berkembang pesat di Indonesia. C2C terbagi menjadi marketplace dan Social Commerce, Marketplace yang digunakan yaitu Tokopedia dan untuk Social Commerce yaitu Facebook dan Instagram.

Kualitas produk olahan lidah buaya mampu dipertahankan oleh pemilik UKM I Sun Vera untuk memenuhi kebutuhan konsumen yang dimana penekanan kualitas produk pada UKM I Sun Vera ini masuk dalam tujuan menengah pada UKM tersebut. Produk olahan lidah buayan yang diproduksi juga selalu dikontrol untuk tetap menjaga kualitas dari produk olahan lidah buaya tersebut. UKM I Sun Vera memasarkan produk dengan harga berkisar antara $\mathrm{Rp} 5000,00$ hingga $\mathrm{Rp}$ 40.000,00. Produk yang dipasarkan secara konvensional dan secara e-commerce tidak memiliki harga yang sama saja. Lokasi toko UKM I Sun Vera berada di Jalan Budi Utomo yaitu J1. Budi Utomo Blok A6 No. 3, Siantan Hulu, Pontianak Utara, Kota Pontianak. Toko online atau penjualan e-commerce produk olahan lidah buaya dapat diakses pada aplikasi tokopedia, instagram dan facebok dengan nama I Sun Vera.

Promosi produk olahan lidah buaya dilakukan dengan melakukan pengembangan produk agar variasi produk yang ditawarkan semakin bertambah. Selain itu juga promosi dilakukan dimedia sosial. Namun, promosi yang dilakukan dimedia sosial masih belum efektif. Kemasan produk olahan lidah buaya UKM I Sun Vera memiliki berbagai macam variasi dan tampilan disetiap produk nya serta tampilan gambar yang diupload pada toko e-commerce memilki kualitas gambar yang bagus dan menarik. UKM I Sun Vera memiliki sejumlah karyawan untuk menunjang proses produksi hingga ke packaging dan pemasarannya baik konvensial maupun $e$ commerce. Namun, tidak semua karyawan mampu mengaplikasikan pemasaran $e$ commerce dan lemahnya karyawan dalam menangani keluhan konsumen ketika konsumen kesulitan berbelanja secara online. Proses pemasaran secara e-commerce UKM I Sun Vera merupakan mekanisme yang digunakan dari mulai konsumen memesan produk secara online, memilih metode pembayaran, memilih jasa pengiriman sampai produk tersebut sampai ke tangan konsumen serta mendapatkan penilaian dari konsumen.

Produk olahan lidah buaya UKM I SUN VERA yang dijual secara e-commerce meliputi: Dodol lidah buaya, nastar lidah buaya, kerupuk aloe vera, teh lidah buaya, stick aloe vera, coklat lidah buaya, Jelly lidah buaya dan minuman lidah buaya. Pelaksanaannya pemasaran produk olahan lidah buaya secara e-commerce belum dapat dikatakan maksimal dikarenakan adanya beberapa hambatan diantaranya promosi penjualan yang dilakukan kurang maksimal, tenaga kerja yang kurang terampil, terbatasnya pengetahuan tentang aplikasi atau sistem bisnis online sehingga keputusan pembelian konsumen rendah terhadap produk I SUN VERA. Keputusan pembelian merupakan suatu pertimbangan bagaimana strategi pemasaran yang akan dilakukan oleh perusahaan berikutnya dan hal penting yang 
harus diperhatikan (Fan \& Li, 2009). Keputusan pembelian diukur menggunakan indikator pengenalan kebutuhan, pencarian informasi, evaluasi alternatif, keputusan membeli dan perilaku pasca pembelian (Kotler \& Amstrong, 2012).

Penelitian terdahulu menyebutkan bahwa dimensi bauran pemasaran produk, harga dan proses berpengaruh terhadap keputusan pembelian (Aziz, 2015). Peningkatkan daya saing UKM serta untuk mendapatkan peluang ekspor dan peluang bisnis lainnya dapat dilakukan dengan memanfaatkan perkembangan teknologi informasi, utamanya e-commerce, tidak hanya memanfaatkan internet sebagai tempat untuk melakukan promosi atau mencari peluang bisnis, tetapi juga harus diimbangi dengan manajemen administrasi yang baik melalui penggunaan software yang tepat (Nuryanti, 2013). Menurut (Sujadmika, 2017) kemudahan merupakan faktor yang sangat berpengaruh terhadap proses keputusan pembelian secara e-commerce. Ketika melakukan pembelian secara e-commerce konsumen menginginkan kemudahan yang dimana konsumen tidak perlu keluar rumah dan tidak harus berdesak-desakkan untuk memperoleh produk yang diinginkan. Selain itu juga konsumen dimudahkan dalam transaksi pembayaran yang dapat diakses dimana saja dan kapan saja.

Pemasaran secara e-commerce dilakukan untuk meningkatkan keputusan pembelian suatu produk, penelitian ini menggunakan pendekatan pemasaran yaitu bauran pemasaran. Bauran pemasaran yang diperluas untuk memasukkan produk yang merupakan layanan dan bukan hanya hal-hal fisik. Bauran pemasaran terdapat seperangkat alat pemasaran yang dikenal dengan marketing mix 4P, yaitu produk, harga, lokasi, dan promosi, sedangkan dalam pemasaran jasa memiliki beberapa alat pemasaran tambahan seperti orang, bukti fisik, dan proses (Kotler \& Philip, 2012). Bauran pemasaran yang digunakan dalam penelitian ini merupakan bauran pemasaran 7P yang meliputi produk, harga, promosi, lokasi, bukti fisik, orang/karyawan dan proses. Bauran pemasaran 7P ini digunakan oleh UKM I SUN VERA tetapi belum maksimal. Adanya masalah tersebut maka tujuan dari penelitian ini yaitu untuk mengetahui pengaruh bauran pemasaran terhadap keputusan pembelian secara e-commerce UKM I Sun Vera. Pentingnya penelitian ini adalah memberikan bahan informasi dan masukan strategi bagi UKM I Sun Vera dalam meningkatkan pemasaran secara e-commerce dan menentukan kebijakan secara tepat guna mencapai pemasaran e-commerce yang maksimal.

\section{METODE PENELITIAN}

Penelitian Metode penelitian yang digunakan adalah metode kuantitatif dengan pendekatan penelitian deskriptif. Sampel dalam penelitian ini berjumlah 110 responden dengan teknik pengambilan sampel menggunakan pendekatan purposive sampling. Teknik pengumpulan data dilakukan melalui wawancara dengan menyebarkan link kuesioner secara online. Variabel laten endogen diukur melalui bauran pemasaran 7P yaitu produk (kualitas produk, variasi produk), harga (keterjangkauan harga, kesesuaian harga, daya saing harga), promosi (potongan harga, iklan), lokasi (online marketplace, sosial media), bukti fisik (tampilan gambar, packaging), orang (Kecepatan karyawan dan ketanggapan karyawan) dan proses (kemudahan metode pembayaran, kemudahan proses klaim) sedangkan variabel laten eksogen diukur melalui keputusan pembelian. Alat analisis pada penelitian ini menggunakan analisis structural equation modelling (SEM). 


\section{HASIL DAN PEMBAHASAN}

Karakteristik responden dapat diklasifikasikan berdasarkan jenis kelamin, usia, agama, pendidikan, pekerjaan, penghasilan.

Tabel. 1 Karakteristik Responden

\begin{tabular}{|c|c|c|c|}
\hline $\begin{array}{c}\text { Karakteristik } \\
\text { Responden }\end{array}$ & Keterangan & Frekuensi & $\begin{array}{c}\text { Persentase } \\
(\%)\end{array}$ \\
\hline \multirow[t]{2}{*}{ Jenis Kelamin } & Laki-Laki & 29 & 26 \\
\hline & Perempuan & 81 & 74 \\
\hline \multirow[t]{5}{*}{ Usia Responden } & $17-25$ & 20 & 18 \\
\hline & $26-35$ & 53 & 48 \\
\hline & $36-46$ & 24 & 22 \\
\hline & $46-55$ & 11 & 10 \\
\hline & $>55$ & 2 & 2 \\
\hline \multirow[t]{5}{*}{ Pendidikan } & $\mathrm{Sd}$ & 7 & 6 \\
\hline & SMP & 18 & 16 \\
\hline & SMA & 51 & 46 \\
\hline & $\mathrm{S} 1$ & 33 & 31 \\
\hline & $\mathrm{S} 2 / \mathrm{S} 3$ & 1 & 1 \\
\hline \multirow[t]{5}{*}{ Pekerjaan } & Swasta & 18 & 19 \\
\hline & Pegawai Negeri & 15 & 14 \\
\hline & Wiraswasta & 23 & 20 \\
\hline & IRT & 38 & 33 \\
\hline & Pelajar/mahasiswa & 16 & 14 \\
\hline \multirow[t]{5}{*}{ Penghasilan } & $<\operatorname{Rp} 1.000 .000-\operatorname{Rp} 2.000 .000$ & 25 & 23 \\
\hline & Rp 2.000.000 - Rp 3.000.000 & 16 & 14 \\
\hline & Rp 3.000.000 - Rp 4.000.000 & 26 & 24 \\
\hline & $\mathrm{Rp} 4.000 .000-\mathrm{Rp} 5.000 .000$ & 8 & 7 \\
\hline & $>$ Rp 5.000.000 & 35 & 32 \\
\hline Rata-rata & $1-3$ jam & 63 & 57 \\
\hline penggunaan & 4-7 jam & 37 & 34 \\
\hline Internet & $>7$ jam & 10 & 9 \\
\hline Tempat & Facebook & 16 & 15 \\
\hline \multirow{2}{*}{ Pembelian produk } & Instagram & 50 & 45 \\
\hline & Tokopedia & 44 & 40 \\
\hline Alasan Pembelian & Produk Bermanfaat & 48 & 44 \\
\hline \multirow[t]{3}{*}{ Produk } & Pelayanan Baik & 22 & 20 \\
\hline & Informasi Menarik & 16 & 15 \\
\hline & Rekomendasi Orang lain & 24 & 21 \\
\hline Frekuensi & Pertama Kali & 15 & 14 \\
\hline \multirow[t]{2}{*}{ Pembelian } & 2-5 Kali & 73 & 66 \\
\hline & $>5$ Kali & 22 & 20 \\
\hline
\end{tabular}

Sumber: Data Analisis, 2019

Jenis kelamin responden pada penelitian tentang kegiatan pembelian produk olahan lidah buaya UKM I Sun Vera didominasi oleh perempuan. Hal ini dikarenakan selain perempuan umumnya mendominasi pola suka berbelanja dan pengambilan keputusan bidang pengeluaran keluarga, berbelanja secara e-commerce juga memudahkan seseorang dengan tidak perlu keluar rumah dan berdesak-desakan ditoko. Sebagai ibu rumah tangga yang menyiapkan makanan bagi keluarga maka seorang ibu rumah tangga lebih sering menghabiskan waktu untuk berbelanja dalam memenuhi kebutuhan keluarga (Widiyanto, Adhi, \& Daryanto, 2016). 
Berbelanja secara e-commerce memberikan berbagai informasi dan memberikan keleluasaan untuk mendapatkan dan membeli barang yang dibutuhkan konsumen. Ketika konsumen membutuhkan produk yang sulit dicari pada toko offline, kemudian konsumen tersebut mencari produk secara online dan menemukan produk yang dibutuhkan. Kegiatan pencarian dan pembelian produk melalui e-commerce konsumen bisa memperoleh barang-barang lebih exclusive karena tidak tersedia secara massal serta harga yang ditawarkan lebih murah biasanya diperoleh langsung dari distributor (Lestari, 2015)

Umur responden yang paling dominan yaitu berusia 26-35 tahun,karena mayoritas orang berbelanja secara e-commerce adalah orang-orang yang relatif muda (Sudjatmika, 2017). Hal ini mengungkapkan bahwa responden pada umur tersebut sangat familiar menggunakan teknologi kemudian dijadikan sasaran oleh perusahaan-perusahaan e-commerce untuk hal promosi serta segmen terbesar konsumen melakukan keputusan pembelian secara e-commerce (Tashandra, 2018).

Pendidikan responden yang paling dominan adalah pada tingkat SMA, karena tingkat pendidikan terakhir SMA maupun Perguruan Tinggi lebih mengenal teknologi dan mengerti cara berbelanja secara e-commerce (Sudjatmika, 2017).

Tingkat pekerjaan responden yang dominan yaitu pada Ibu rumah tangga, karena sebagai ibu rumah tangga lebih sering terhubung ke internet dan umumnya wanita dominan menyukai berbelanja secara e-commerce (Sudjatmika, 2017).

Penghasilan responden yang lebih dominan yaitu penghasilan di atas Rp. 5.000.000, karena mayoritas pembeli adalah ibu rumah tangga yang menyukai berbelanja secara e-commerce dan berpenghasilan tinggi dapat meningkatkan pembeliannya terhadap produk secara e-commerce (Sudjatmika, 2017). Hal ini sejalan dengan penelitan bahwa semakin tinggi penghasilan maka akan semakin tinggi pula tingkat pembelian produk oleh konsumen (Indriani, 2015).

Saat ini jumlah pengguna internet di Indonesia mengalami kenaikan yaitu mencapai 171 juta jiwa dari seluruh total penduduk indonesia yaitu 269 juta jiwa atau setara dengan 64,67 \% (APJJI, 2018). Rata-rata responden mengakses internet yang tertinggi yaitu selama 1-3 jam, kemudian 4-7 jam, dan tingkatan terendah yaitu pada rata-rata responden menggunakan internet selama lebih dari 7 jam. Hal ini sejalan dengan hasil survei penetrasi pengguna internet yang tertinggi yaitu pada responden dengan rata-rata $1-3$ jam dan digunakan untuk berbelanja secara $e$ commerce.

Tempat pembelian produk olahan lidah buaya secara e-commerce dominan pada media instagram. Media sosial yang paling sering digunakan di Indonesia adalah media sosial Instagram. Hasil penyebaran kuesioner mendapatkan hasil bahwa responden paling tinggi dalam menggunakan media sosial Instagram. Hal ini sejalan dengan hasil survei Ekosistem DNA (Device, Network and Application) dan Awaraness yang dilakukan oleh Masyarakat Telematika Indonesia (MASTEL) dan Asosiasi Penyelenggara Jasa Internet Indonesia (APJII) 2016, menyebutkan bahwa instagram digunakan oleh $82,6 \%$ responden penelitian tersebut, sementara facebok sebesar $66,5 \%$. Responden melakukan pembelian pada tokopedia.com mencapai 40\%. Saat ini tokopedia.com mengklaim telah menjangkau 97 kecamatan di Indonesia dengan pengguna aktif mencapai 90 juta pengguna. Hal ini dapat dijadikan peluang bagi owner UKM I Sun Vera untuk lebih mengembangkan lagi pemasaran produk secara e-commerce karena peluangnya cukup besar dengan dilihat dari peningkatan jumlah pengguna internet di Indonesia. 
Alasan utama responden membeli produk olahan lidah buaya dominan pada produk tersebut bermanfaat bagi tubuh dan adanya kemudahaan dalam pembelian produk olahan lidah buaya secara e-commerce. hal ini dibenarkan oleh hasil penelitian bahwa lidah buaya memiliki kandungan berupa saponin, flavonoid, polifenol serta tanin yang mempunyai kemampuan membersihkan serta sebagai antiseptik, gel lidah buaya juga mengandung 17 asam amino yang penting bagi tubuh (Hariana, 2004); (Djubaedah, E., 2003).

Pengalaman pembelian responden dominan pada pembelian 2-5 kali. Tingkat pengalaman pembelian barang konsumen yang lebih tinggi menentukan kemungkinan masa depan membeli, mengunjungi toko, merekomendasikan orang lain dan lebih sering berbelanja dalam hal menerima pendapatan yang lebih tinggi (Wongleedee, 2015). Hubungan antara frekuensi pembelian dan kemungkinan kunjungan rutin untuk berbelanja di toko e-commerce di Indonesia masa depan dan merekomendasikan orang lain untuk melakukannya. Dengan hasil yang mendominasi maka berbelanja secara e-commerce merupakan gaya hidup masyarakat saat ini (Sudjatmika, 2017).

\section{Uji Kecocokan Model (Goodness Of Fit)}

Berdasarkan hasil uji kecocokan model GOF setelah di respisifikasi, terjadi perubahan indeks kecocokan yang diketahui bahwa 16 dari 19 ukuran GOF sudah masuk ke dalam kriteria baik dan 3 ukuran GOF kurang baik setelah dilakukan modifikasi indeks atau respesifikasi. Ukuran tersebut diantaranya yaitu $\mathrm{X}^{2} / \mathrm{DF}, \mathrm{NCP}$, SNCP, RMSEA, ECVI, AIC, CAIC, NFI, NNFI, CFI, IFI, GFI, AGFI, PGFI, dan RMR, sedangkan 3 kriteria lainnya masih kurang baik yaitu PNFI, RFI, CN.

\section{Analisis Hubungan Antar Variabel Structural Equation Modelling (SEM)}

Berdasarkan hasil estimasi model yang telah mengalami perbaikan, diperoleh koefisien-koefisien yang dapat menunjukkan hubungan antar variabel (gambar 1 dan 2).

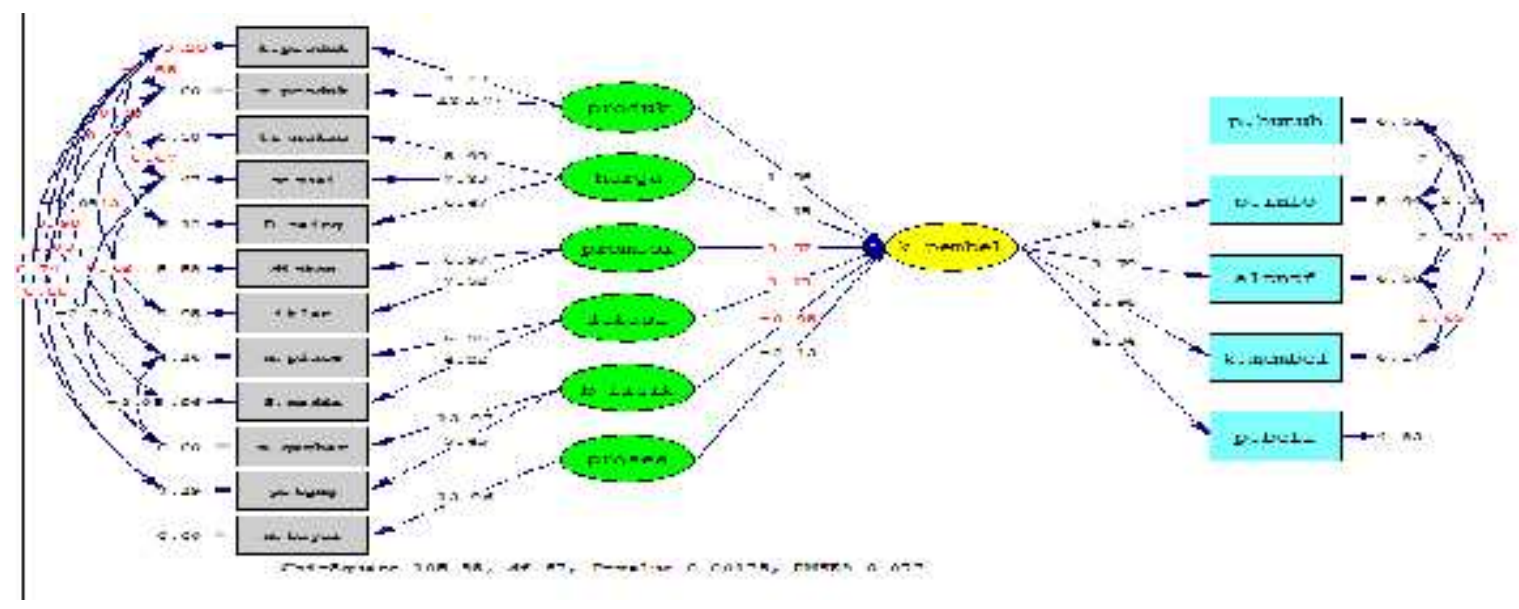

Gambar 1. T-value 


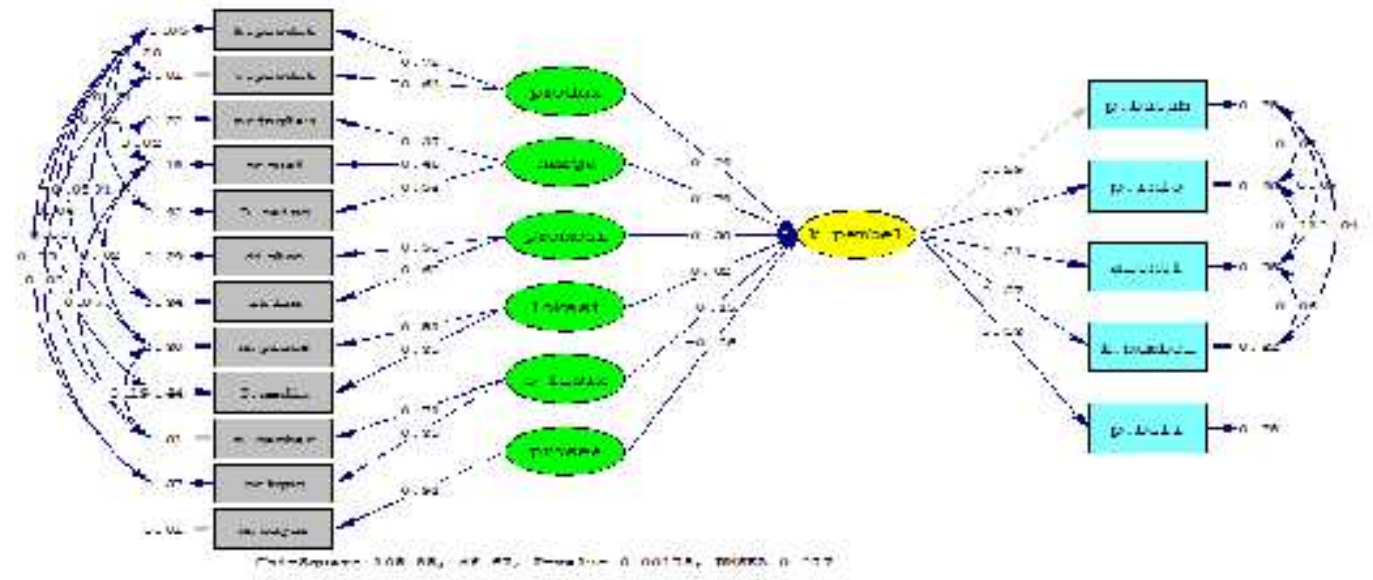

Gambar 2. Koefisien Estimasi

Sumber: Analisis data primer, 2019

Model struktural menjelaskan bahwa variabel produk, harga dan proses berpengaruh terhadap keputusan pembelian produk olahan lidah buaya secara $e$ commerce. Hasil ini relevan dengan penelitian lain yang menyatakan bahwa variabel produk, harga dan proses berpengaruh terhadap keputusan pembelian secara $e$ commerce (Ramadhanti, 2017). Unsur dalam bauran pemasaran yang pertama dan paling penting yaitu bauran pemasaran produk, bauran pemasaran produk dimulai dengan melakukan suatu penawaran yang dapat memenuhi keinginan dan kebutuhan konsumen. Hal ini lah yang membuat produk berpengaruh terhadap keputusan pembelian secara e-commerce produk olahan lidah buaya (Kotler P. , 2000). Deskripsi suatu produk pada media online berpengaruh terhadap kesadaran konsumen. Deskripsi produk yang menarik, tampilan produk secara gambar juga dapat menentukan keberhasilan pemasaran suatu produk secara e-commerce (Setiawan, Suharjo, \& Syamsun, 2018).

Variabel harga berpengaruh positif, artinya jika variabel produk ditingkatkan maka akan meningkatkan keputusan pembelian produk olahan lidah buaya secara e-commerce. Variabel harga berpengaruh terhadap keputusan pembelian produk (Widiyanto, Adhi, \& Daryanto, 2016). Berbelanja secara e-commerce memudahkan konsumen dalam membandingkan harga produk pada toko e-commerce yang berbeda. Bukan hanya dari segi harga jual, tetapi konsumen dapat membandingkan promo-promo yang sedang diberikan dari masing-masing toko e-commerce sehingga konsumen mendapatkan penawaran harga produk yang baik (Setiawan, Suharjo, \& Syamsun, 2018).

Variabel proses berpengaruh signifikan terhadap keputusan pembelian olahan lidah buaya secara e-commerce. Ketika melakukan pembelian suatu produk secara e-commerce konsumen melalui proses yang lebih mudah dan praktis serts konsumen tidak perlu keluar rumah untuk membeli produk yang dibutuhkan cukup dengan melihat produk-produk yang dipasarkan secara online di media sosial maupun di internet serta proses pemesanan sampai pengiriman produk yang cepat dan dapat dilacak sendiri. Hal ini yang menjadi alasan konsumen lebih memilih berbelanja secara e-commerce. Proses dalam pembelian secara e-commerce memiliki langkah yang berbeda daripada pembelian konvensional. Kekhasan dari proses pembelian produk secara e-commerce adalah ketika konsumen yang berpotensial menggunakan internet dan mencari-cari informasi yang berkaitan dengan barang yang dibutuhkan (Setiawan, Suharjo, \& Syamsun, 2018). Konsumen percaya bahwa 
akan mendapatkan keuntungan yang lebih besar ketika membeli produk secara $e$ commerce daripada membeli secara konvensional (Prabowo, Darman, \& Noegraheni, 2014).

Variabel promosi tidak berpengaruh signifikan, artinya semakin rendah persepsi konsumen terhadap promosi, maka akan semakin lemah mendorong konsumen untuk melakukan keputusan pembelian untuk membeli produk olahan lidah buaya secara e-commerce (Budiyanto, Christoffel, \& Hendra, 2016). Promosi dimedia sosial dilakukan dengan cara menyebar konten informasi, promosi atau pun ilmu yang dapat memberikan manfaat pada konsumen. Ketika produsen ingin memasarkan produk olahan lidah buaya, maka informasi yang dapat dibagikan seperti manfaat dari lidah buaya atau pun khasiatnya. Promosi dapat juga dengan mengadakan giveaway yang menarik dengan hadiah produk olahan lidah buaya tersebut. Promosi yang dilakukan oleh UKM I Sun Vera masih efektif karena kurangnya informasi yang dibagikan oleh UKM tersebut. Hasil penelitian ini tidak relevan dengan penelitian yang menyatakan bahwa promosi dimedia sosial berpengaruh terhadap keputusan pembelian (Pamungkas $\&$ Zuhroh, 2016). Variabel lokasi tidak berpengaruh signifikan terhadap keputusan pembelian secara $e$ commerce. Artinya jika variabel lokasi ditingkatkan maka akan tidak akan meningkatkan keputusan pembelian produk olahan lidah buaya secara e-commerce. Lokasi dalam e-commerce dapat disebut juga dengan media pemasaran. Media pemasaran yang digunakan oleh UKM I Sun Vera dalam memasarkan produknya yaitu melalui media instagram, facebook dan tokopedia.com. Variabel bukti fisik tidak berpengaruh, artinya jika variabel bukti fisik ditingkatkan maka tidak akan meningkatkan keputusan pembelian produk olahan lidah buaya secara e-commerce. Hasil penelitian ini relevan dengan penelitian yang menyatakan bahwa bukti fisik tidak berpengaruh tehadap keputusan pembelian (Ramadhanti, 2017).

Model pengukuran menjelaskan hubungan antar variabel laten dengan pengukurannya. Indikator kualitas produk berkontribusi pada keputusan pembelian produk olahan lidah buaya oleh konsumen. Indikator kualitas produk mempunyai respon positif terhadap keputusan pembelian dan penting bagi produsen untuk lebih meningkatkan kualitas produknya (Rizan, et al, 2015); (Dani R. , 2014). Indikator variasi produk berkontribusi pada produk untuk mendukung keputusan pembelian produk olahan lidah buaya oleh konsumen. Variasi produk berpengaruh simultan terhadap keputusan pembelian produk (Isti, Leonardo, \& Maria, 2016). Adanya pengaruh variasi produk terhadap keputusan pembelian konsumen ini berarti produsen penting untuk membuat berbagai variasi produk untuk meningkatkan keputusan pembelian produk secara e-commerce.

Indikator keterjangkauan harga signifikan berpengaruh positif, dan berkontibrusi pada variabel harga untuk mendukung keputusan pembelian olahan lidah buaya secara e-commerce. Semakin relatifnya harga yang diberikan kepada konsumen, maka semakin cepat konsumen untuk memutusan pembelian produk olahan lidah buaya secara e-commerce (Widiyanto, Adhi, \& Daryanto, 2016). Indikator kesesuaian harga berkontribusi terhadap variabel harga untuk mendukung keputusan pembelian produk olahan lidah buaya oleh konsumen. Hasil penelitian ini relevan dengan penelitian yang menyebutkan bahwa kesesuaian harga berpengaruh terhadap keputusan pembelian produk oleh konsumen (Mariana, 2015). Kesesuaian harga diartikan sebagai harga yang sesuai dengan kualitas produk suatu barang, dan harga tersebut dapat memberikan kepuasan konsumen 
(Ngadiman, 2008). Indikator daya saing berkontribusi terhadap variabel harga untuk mendukung keputusan pembelian produk olahan lidah buaya secara e-commerce oleh konsumen. Apabila semakin tinggi suatu harga atau semakin tidak terjangkau suatu harga yang ditawarkan oleh produsen, maka konsumen akan berpindah ke produk yang sesuai dengan daya belinya (Mariana, 2015).

Indikator kemudahan dalam metode pembayaran yang mempunyai beberapa alternatif, dimana pembayaran dapat dilakukan pada hari libur maupun hari hari lainnya dengan proses yang mudah dan cepat. Pembelian yang ditawarkan dalam pembelian produk secara e-commerce biasanya lebih baik dari produk yang ditawarkan dalam pembelian offline, kemudahan sering menjadi salah satu daya tarik. Kemudahan akses memilih produk, kemudahan dalam melakukan pembelian, kemudahan pembayaran sampai dengan kemudahan mendapatkan produk atau pengiriman. Kemudahan metode pembayaran konsumen diberikan fasilitas dan alur cara pembayaran yang membuat kenyamanan dalam melakukan pembelian jadi yang utama. Persepsi kemudahan transaksi online mengacu pada persepsi individu akan mudahnya transaksi belanja online yang dilakukan. Ketika melakukan transaksi, konsumen hanya melakukan sedikit usaha, tidak terlalu ribet sehingga memudahkan konsumen tersebut melakukan keputusan pembelian produk melalui online. Persepsi kemudahan transaksi dapat berupa prosedur pemesanan, prosedur pembayaran yang variatif dan mudah dilakukan, proses pembelian yang informatif dan menyenangkan serta proses pengiriman produk yang cepat dan tepat (Widiyanto $\&$ Prasilowati, 2015). Perilaku pembeli online sangat bergantung pada ketersediaan informasi dan kemudahan dalam melakukan transaksi online (Shim \& Shin, 2002).

Indikator Potongan harga tidak berkontribusi terhadap promosi untuk mendukung keputusan pembelian produk olahan lidah buaya secara e-commerce, hal ini dikarenakan potongan harga yang diberikan oleh produsen UKM I Sun Vera tidak sesuai dengan keinginan konsumen. Konsumen menginginkan UKM I Sun Vera sering mengadakan jawaban sering mengadakan promo buy one get one, gratis ongkir, cashback, dan memberikan voucer, sedangkan untuk indikator iklan yang di media online memberikan informasi yang akurat dan sesuai kebenarannya. Hal itu dikarena responden ketika akan membeli produk secara online akan lebih mementingkan informasi yang sesuai dengan kebenarannya agar tidak merasa kecewa setelah membeli produk dan produk yang dibelinya tidak sesuai dengan apanya dibayangkan dibenak konsumen. Untuk itu iklan dituntut mampu memberikan informasi, manfaat produk yang ditawarkan, memberikan kesan rasa percaya dan menarik perhatian calon konsumen (Kotler \& Keller, 2013). UKM I Sun Vera harus mempromosikan produknya secara akurat dan sesuai dengan kebenaran dari produk tersebut. Kurangnya kualitas informasi yang didapatkan konsumen dalam media online akan membatasi keputusan konsumen untuk membeli secara online dan tidak akan memotivasi konsumen untuk melakukan proses keputusan pembelian (Penia \& Putu, 2016).

Variabel lokasi diukur melalui indikator online marketplace dan sosial media, yang ini berarti tempat atau situs yang dikunjungi. Indikator online marketplace tidak sesuai dengan keinginan konsumen yang menginginkan situs online marketplace pada ulasannya memberikan penilaian dan gambar, karena pada dasarnya konsumen sebelum membeli sebuah produk mereka akan melihat penilaian toko tersebut dan komentar yang menunjukan gambar dari konsumen yang telah membeli produk tersebut sebelumnya (Ahmad, Imam, \& Berto, 2016). 
Indikator sosial media juga tidak sesuai dengan keinginan konsumen. Keinginan konsumen pada media sosial dominan menjawab bahwa sosial media memberikan informasi 4-5 minggu. Media sosial menjadi media yang paling ampuh untuk dijadikan media promosi, bahkan media sosial juga dijadikan sebagai tempat pemasaran yang interaktif, pelayanan, dan membangun hubungan dengan konsumen secara online (Siswanto, 2013).

Indikator tampilan gambar tidak berkontribusi pada variabel bukti fisik dalam mendukung keputusan pembelian produk olahan lidah buaya secara e-commerce. Indikator tampilan gambar yang didapat bahwa konsumen produk olahan lidah buaya dominan menginginkan tampilan gambar yang memiliki ciri khas asal Pontianak dan pemilik I Sun Vera, karena tampilan gambar yang memiliki ciri khas tertentu dapat menarik minat beli konsumen untuk melakukan keputusan pembelian (Margaretha, S., Edwin, \& Japarianto, 2012). Peningkatan variabel bukti fisik digunakan untuk menarik kembali minat konsumen melakukan pembelian produk olahan lidah buaya secara e-commerce. Variabel bukti fisik, hal yang dinilai masih kurang optimal yaitu tentang keinginan packaging konsumen. Packaging yang diinginkan oleh konsumen didapat dari hasil kuesioner yang mayoritas jawaban responden memilih warna packaging dihiasi dengan berbagai macam warna, warna cerah dan tulisan yang mudah dibaca, karena packaging yang memiliki berbagai macam warna dan gambar menarik akan mempengaruhi keinginan konsumen untuk membeli produk (Lena \& Anisa, 2008).

\section{KESIMPULAN DAN SARAN}

\section{Simpulan}

Hasil penelitian menunjukan bahwa bauran pemasaran produk, harga dan proses berpengaruh terhadap keputusan pembelian produk olahan lidah buaya secara e-commerce. Sedangkan bauran pemasaran promosi, lokasi dan bukti fisik tidak berpengaruh terhadap keputusan pembelian produk olahan lidah buaya secara e-commerce. Pengaruh tertinggi terdapat pada variabel harga, dimana harga produk tersebut terjangkau oleh konsumen dan memiliki kesesuaian harga dengan ukuran dari produk olahan lidah buaya, dan memiliki tingkat daya saing harga yang sesuai dengan daya beli konsumen tersebut.

\section{Saran}

UKM I Sun Vera harus memperhatikan kandungan nutrisi produk pada kemasan serta menambah variasi produk yang diunggah dalam media pemasaran online. UKM I Sun Vera juga harus memperhatikan keterjangkauan harga produk dengan membuat inovasi produk ke dalam berbagai ukuran bentuk dan kemasan serta dengan menambah alternatif pembayaran online guna memudahkan konsumen dalam hal pembayaran seperti Dana, Gopay, Alfamart/Indomaret, Cash on Delivery dan lainnya.

\section{DAFTAR PUSTAKA}

Ahmad, F., Imam, B., \& Berto, M. W. (2016). Pengaruh Online Customer Review Dan Rating Terhadap Kepercayaan Dan Minat Pembelian Pada Online Marketplace Di Indonesia. Jurnal Teknik Its, 5(2), 1-6.

APJII. 2018. Hasil Survei Penetrasi Pengguna Internet Indonesia. APJII 
Budiyanto, T., C. K., \& H. N. (2016). Strategi Promosi, Kualitas Produk, Dan Desain Terhadap Keputusan Pembelian Produk Ikan Kaleng (Sarden) Merk Maya. Jurnal Berkala Ilmiah Efisiensi, 16(4), 1-13.

Dani, R. (2014). Analisis Respon Konsumen Pada Kualitas Produk Kuliner (Ayam Penyet Pak Ulis Cabang Pekanbaru). Jurnal Online Mahasiswa (Jom) Fisip, 1(2), 1-19.

Djubaedah, E. (2003). Pengolahan Lidah Buaya Dalam Sirup. Bogor: Pra-Forum Apresiasi Dan Komersialisasi Hasil Riset. Balai Besar Industri Agro.

Eliza, Sayamar, E., \& Kaswita, C. (2011). Analisis Faktor-Faktor Yang Mempengaruhi Konsumen Dalam Pengambilan Keputusan Pembelian Konsumen Buah Di Pasar Arengka. Indonesian Journal of Agricultural Economics (IJAE), 2(1), 1 20

Fan, Y., \& Li, Y. (2009). Children's Buying Behaviour In China: A Study of Their Information Sources. Marketing Intelligence and Planning, 27(2), 1-31

Ghozali, I. (2012). Structural Equation Modeling Teori, Konsep Dan Aplikasi Dengan Program Lisrel 8.80. Semarang: Badan Penerbit Universitas Diponegoro.

Hariana, A. (2004). Tumbuhan Obat Dan Khasiatnya. Jakarta: Penebar Swadaya.

Haryanto, A. T., \& Dewi, S. N. (2016). Pengaruh Kepuasan Konsumen Sebagai Mediator Bauran Pemasaran Terhadap Keputusan Pembelian (Studi Pada Rumah Makan Pondok Padi Organik di Sragen). Journal of Economic Education, 5(2), 1-8.

Isti, F., Leonardo, B., \& Maria, M. (2016). Analisis Pengaruh Variasi Produk, Fasilitas, Dan Kualitas Pelayanan Terhadap Minat Beli Ulang Konsumen Pada Indonesian Coffeeshop Semarang (Icos Café). Journal ff Management, 2(2), 1 13

Jurnia, Meri \& Udung N. Rosyad. 2015. Kajian Hubungan Antara Iklan di Media Sosial Dengan Minat Beli Konsumen. Jurnal Bisnis dan Ekonomi, 2(4), 12-18.

Kotler, P., \& Amstrong, G. (2014). Principle of Marketing. New Jersey: Pearson Pretice Hall.

Lena, Nuryanti, and Yunia Rahman Anisa. Pengaruh Variasi Dan Kemasan Produk Terhadap Keputusan Pembelian Teh Kotak Ultrajaya. Jurnal Strategic, 7(14), $1-13$

Lestari, S. B. (2015). Shopping Online Sebagai Gaya Hidup. Jurnal Ilmu Sosial, 14(2), 24-41.

Margaretha, S., F., Edwin, \& Japarianto. (2012). Analisa Pengaruh Food Quality Dan Brand Image Terhadap Keputusan Pembelian Roti Kecik Toko Roti Ganep's di Kota Solo. Jurnal Manajemen Pemasaran, 1(1), 1-6.

Mariana. (2015). Pengaruh Kualitas Produk dan Harga Terhadap Keputusan Pembelian Produk Industri UKM Amplang Ud. Sinar Rejeki di Samarinda. ejournal Ilmu Administrasi Bisnis, 3(2) 388-402. 
Mugaonkar, Ananthan, Samal, \& Debnath. (2011). Studi Tentang Perilaku Konsumen. Pertanian Ulasan Penelitian Ekonomi, 24(5), 133-140.

Ngadiman, D. (2008). Marketing Jilid 2. Jakarta: Departemen Pendidikan Nasional.

Pamungkas, B. A., \& Zuhroh, S. (2016). Pengaruh Promosi Di Media Sosial Dan Word Of Mouth Terhadap Keputusan Pembelian (Studi Kasus Pada Kedai Bontacos Jombang). Jurnal Komunikasi, 10(2), 145-160.

Penia, A., \& Putu, N. M. (2016). Pengaruh Kepercayaan Dan Kualitas Informasi Terhadap Keputusan Pembelian Secara Online Pada Situs Traveloka.Com. EProceeding of Management, 3(2), 1880

Prabowo, H., Darman, \& Noegraheni, E. (2014). Analisis Kepercayaan Dalam C2c ECommerce Terhadap Keputusan Pembelian Dan Dampaknya Terhadap Repurchase Pada Kaskus. Binus Busines Review, 5(1), 301-314.

Ramadhanti, A. (2017). Pengaruh Bauran Pemasaran (7P) Terhadap Keputusan Pembelian Pada Giant Supermarket Mall Mesra Indah Di Samarinda. Ejournal Administrasi Bisnis, 5(2),269-282

Rizan, M., Handayani, K., \& Kresnamurti, A. (2015). Pengaruh Citra Merek Dan Kualitas Produk Terhadap Keputusan Pembelian (Studi Banding Konsumen Indomie Dan Mie Sedaap). Jurnal Riset Manajemen Sains Indonesia, 6(1), 457478.

Setiawan, T. F., Suharjo, B., \& Syamsun, M. (2018). Strategi Pemasaran Online Umkm Makanan. Jurnal Manajemen Ikm, 13(3), 116-126.

Shim, J. P., \& Shin, Y. B. (2002). Retailer Web Site Influence on Customer Shopping: An Exploratory Study on Key Factors of Customer Satisfaction. Journal of The Association for Information Systems, 3(2), 53-76.

Siswanto, Tito. 2013. Optimalisasi Sosial Media sebagai Media Pemasaran Usaha Kecil Menengah. Jurnal Liquidity, 2(1),80-86.

Sudjatmika, F. V. (2017). Pengaruh harga, ulasan produk, kemudahan dan keamanan terhadap keputusan pembelian secara online di Tokopedia.com. Jurnal Agora, 1-7.

Turban. 2002. Electronic Commerce: A Management Prespective International Edition.USA. Prentice Hall

Tashandra, N. (2018, 03 22). kompas.com. Retrieved 09 28, 2019, from 80 Persen Konsumen Belanja Online Orang Muda dan Wanita: https://lifestyle.kompas.com/read/2018/03/22/155001820/80-persenkonsumen-belanja-online-orang-muda-dan-wanita?page=all

Widiyanto, N. A., Adhi, A. K., \& Daryanto, H. K. (2016). Atribut-Atribut Yang Memengaruhi Sikap Dan Preferensi Konsumen Dalam Membeli Buah Apel Di Kota Surabaya Dan Kota Malang, Provinsi Jawa Timur. Jur. Ilm. Kel. \& Kons., 9(2), 1-11.

Wijanto, S. (2008). Structural Equation Modelling Dengan Lisrel 8.8. Yogyakarta: Graha Ilmu. 
Wongleedee, K. (2015). Marketing Mix and Purchasing Behavior for Community Products At Traditional Markets. Procedia Social and Behavioral Sciences 197, 2080-2085. 